\title{
CRUSTAL CONTAMINATION INVERTED: SOME PRELIMINARY RESULTS
}

\author{
MARTA S.M. MANTOVANI* AND CHRIS J. HAWKESWORTH**
}

\begin{abstract}
Wall rock assimilation and fractional crystallization (AFC) as Bowen has pointed out in 1928 , should be considered together because the heat required for assimilation can be provided by the latent heat of crystallization of the magmas. This process (AFC) was discussed by several authors, who sought to reproduce observed trends on isotope-isotope and isotope-trace element diagrams. In general, these models were loosely constrained because of the pratical difficulties in handling large numbers of elements and in exploring the relationships between different variables for any data set. In this work, the approach has been to consider many trace elements and isotope ratios simultaneously, to calculate the best fit surface through the analytical data for suites of related samples and to evaluate the relationships between variables in the AFC model for the range of solutions which are consistent with the best-fit surface. This new analysis of the AFC model is illustrated with selected samples from a detailed section through basalts and rhyolites of the Serra Geral Formation in the Paraná Basin sequence. Results appear to be inconsistent with the bulk assimilation of average crustal compositions, but show excellent agreement with the trace element pattern of typical upper crustal melts.
\end{abstract}

\begin{abstract}
RESUMO CONTAMINAÇĀO CRUSTAL INVERSA: ALGUNS RESULTADOS PRELIMINARES. $\mathrm{O}$ processo que considera a assimilaçăo da rocha encaixante concomitantemente à cristalização fracionada por um determinado magma foi inicialmente enunciado por Bowen e recentemente equacionado por De Paolo, sendo conhecido como processo AFC. Os modelos AFC disponf́veis na literatura têm-se baseado nas tendências observadas em diagramas isolados que relacionam de várias formas concentrações de elementos-traços e razőes isotøpicas. Em geral, esses modelos não são bem vinculados devido ao grande número de elementos envolvidos e, conseqüentemente, de variáveis em cada conjunto de dados. No presente trabalho consideram-se simultaneamente vários elementos bem como razőes isotópicas e calcula-se a superff́cie de melhor ajuste por meio de todos os dados analíticos disponf́veis de uma seqüência de amostras geneticamente correlacionadas. Os parâmetros obtidos são consistentes com uma das soluçőes que satisfazem diferenças mínimas entre os dados analíticos e o modelo calculado. O tratamento numérico utilizado nesta nova análise de modelo AFC $\varepsilon$ aqui descrito, testado com dados sintéticos e aplicado a uma seqüência basáltica da Formação Serra Geral, obtendo-se como resultado a composição de um possf́vel contaminante. São fornecidos todos os parâmetros do modelo, que resultou compatível com um processo AFC tendo como contaminante um material proveniente da fusåo parcial da crosta continental.
\end{abstract}

INTRODUCTION The extent to which continental basalts are affected by interaction with the continental crust, and in particular how such interaction should be established, remains one of the more perplexing problems in modern igneous petrology. Many continental alkali basalt suites have isotope and trace element ratios similar to their oceanic counterparts and would therefore appear to have suffered little contamination en route through the lithosphere. Continental flood basalt provinces, in contrast, exhibit a range of $\mathrm{Sr}-$, $\mathrm{Nd}$-, and $\mathrm{Pb}$-isotopes far greater than that reported from oceanic islands. They equilibrated with mantle source rocks at shallower pressures, and in many cases the range in radiogenic isotope compositions probably reflects contributions from both the mantle and crustal portions of the continental lithosphere.

Early isotope studies were set in a framework which regarded the continental crust as the sole repository of old high $\mathrm{Rb} / \mathrm{Sr}$ and low $\mathrm{Sm} / \mathrm{Nd}$ ratios and hence as the source of high ${ }^{87} \mathrm{Sr} /{ }^{86} \mathrm{Sr}$ and low ${ }^{143} \mathrm{Nd} /{ }^{144} \mathrm{Nd}$. However, studies of mantle xenoliths (Menzies \& Murthy 1980; Erlank et al. 1987) and inclusions in diamonds (Richardson et al. 1984) have since demonstrated that segments of the sub-continental mantle are both old, perhaps locally $3 \mathrm{Ga}$, and have variable $\mathrm{Rb} / \mathrm{Sr}$ and $\mathrm{Sm} / \mathrm{Nd}$ which with time have also generated a wide range in ${ }^{87} \mathrm{Sr} /{ }^{86} \mathrm{Sr}$ and ${ }^{143} \mathrm{Nd} /{ }^{144} \mathrm{Nd}$. Such data highlight the ambiguities of isotope ratios in magmatic rocks and the risks involved in interpreting isotope analyses in isolation from major and trace element results on the same samples.

Contamination of mantle derived melts by crustal material may be considered in two ways: a) the more primitive rocks will tend to be more contaminated because they are hotter and can therefore assimilate more material, and b) the effects of contamination increase with differentiation and so are most marked in the more evolved rock types. The former has shown to be significant in komatiites from the Archaean (Huppert \& Sparks, 1985). However, in the majority of contaminated Phanerozoic and Recent suites ${ }^{87} \mathrm{Sr} /{ }^{86} \mathrm{Sr}$, for example, tends to increase with $\mathrm{SiO}_{2}$ suggesting that contamination processes are linked to differentiation.

Bowen (1928) pointed out that wall rock assimilation and 
fractional crystallization should be considered together, because the heat required for assimilation can be provided by the latent heat of crystallization of the magmas. Several authors, including De Paolo (1981), then discussed models in which fractional crystallization was accompanied by assimilation and sought to reproduce observed trends on isotope-isotope and isotope-trace element diagrams. In general, however, these models were loosely constrained not least because of the practical difficulties in handling large numbers of elements and in exploring the relationships between different variables for any data set.

Our approach has been $i$ ) to consider many trace elements and isotope ratios simultaneously; ii) to calculate the best fit surface through the analytical data for suites of related samples; and iii) then to evaluate the relationships between variables in the assimilation-fractional crystallization (AFC) model for the range of solutions which are consistent with the best-fit surface. This new analysis of the AFC model follows De Paolo (1981) and is illustrated with selected samples from a detailed section through basalts and rhyolites in the south east portion of the Parana Basin.

THEORETICAL BACKGROUND De Paolo (1981, eq. 6) related the concentration of a trace element in a magma by the following equation:

$$
\frac{C_{m}}{C_{o}}=F^{-Z}+\frac{r}{r-1} \frac{1}{z} \frac{C_{a}}{C_{o}}\left(1-F^{-Z}\right)
$$

where $C_{m}, C_{0}$, and $C_{a}$ are the concentration of the trace element in the observed magma, the parental magma (i.e. starting composition) and the assimilated material, respectively. $\mathrm{F}$ is the fraction of the liquid remaining such that

$$
\mathrm{F}=\frac{\mathrm{M}_{\mathrm{o}}-\mathrm{M}_{\mathrm{X}}+\mathrm{M}_{\mathrm{a}}}{\mathrm{M}_{\mathrm{o}}}
$$

where $M_{0} M_{X}$, and $M_{a}$ are the masses of initial magma, crystals, and assimilated material respectively. $\mathrm{r}$ is the rate of assimilation divided by the rate of fractional crystallization, and $\mathrm{Z}$ relates $\mathrm{r}$ and the bulk distribution coefficient $\mathrm{D}$ for the particular trace element as follows:

$$
\mathrm{Z}=\frac{\mathrm{r}+\mathrm{D}-1}{\mathrm{r}-1}
$$

Equation (1) may be simplified so that for any trace element:

$$
\begin{gathered}
\frac{\mathrm{C}_{\mathrm{m}}}{\mathrm{C}_{\mathrm{o}}}=\mathrm{W}+(1-\mathrm{W}) \mathrm{F}^{-\mathrm{Z}} \\
\text { where } \mathrm{W}=\frac{\mathrm{r}}{\mathrm{r}+\mathrm{D}-1} \frac{\mathrm{C}_{\mathrm{a}}}{\mathrm{C}_{\mathrm{o}}}
\end{gathered}
$$

$\mathrm{C}_{\mathrm{m}}$ is the concentration of the element in the magma being modelled, $\mathrm{C}_{\mathrm{O}}$ is the selected starting composition, and $\mathrm{F}, \mathrm{r}, \mathrm{D}$, and $\mathrm{C}_{\mathrm{a}}$ are the unknowns to be calculated from the best fit surface to the data points for all elements.
Equation (1) can be re-arranged so that

$$
F=\left(\frac{\frac{C_{m}}{C_{o}}-W}{1-W}\right)-\frac{1}{z}
$$

and as $\mathrm{F}$ is constant for any sample, the best fit solutions of all elements in a sample will tend to a common value of $F$. Furthermore an approximate lower limit of $\mathrm{F}$ is available from closed system fractional crystallisation models based on major elements (e.g. the XLFRAC programme of Stormer \& Nicholls 1978).

Isotope ratios are incorporated from equation (15a) of De Paolo (1981) which can be rewritten:

$$
\frac{C_{m}}{C_{o}}=\frac{W}{1-O(1-W)}
$$

where $\phi$ expresses the isotope ratios as

$$
\phi=\frac{\mathrm{RI}_{\mathrm{a}}-\mathrm{RI}_{\mathrm{m}}}{\mathrm{RI}_{\mathrm{a}}-\mathrm{RI}_{\mathrm{o}}}
$$

$\mathrm{RI}_{\mathrm{a}}, \mathrm{RI}_{\mathrm{m}}$, and $\mathrm{RI}_{\mathrm{o}}$ are the isotope ratios of the assimilant, the magma being modelled, and the starting composition respectively.

For any sample the change from the starting composition is then described by a set of $\mathrm{N}$ non-linear equations, where $\mathrm{N}$ is the sum of the number of trace elements and isotope ratios being considered. $\mathrm{F}$ is held to be constant for each sample and the unknowns $\mathrm{r}, \mathrm{D}, \mathrm{C}_{\mathrm{a}}$, and $\mathrm{RI}_{\mathrm{a}}$ are expressed in the functions $\mathrm{Z}, \mathrm{W}$, and $\varnothing$, which in turn are set up as parameters in each of the non-linear equations. To describe the AFC process responsible for a trend defined by more than one sample, the number of equations increases to $N \times M$, where $M$ is the number of samples. The number of unknowns for the whole suite is held to be the same as that for each sample, unless is allowed to vary from sample to sample whereupon $(M-1)$ new parameters are added to the set of unknowns.

Such calculations lead to a very large number of mathematically possible solutions, but since a proportion of these are geologically unrealistic, it is necessary to set limiting values for the unknowns (Tab. 3). For example, the bulk distribution coefficient $\mathrm{D}$ for $\mathrm{Sr}$ in a crustal magma chamber is likely to be in the range $0.2-9$ (Henderson 1982). The solutions are also much better constrained if approximate values of $F$, the fraction of liquid remaining, can be estimated independently perhaps from the major element data.

The non-linear least squares fitting of $\mathrm{N} \mathrm{x}$ M equations (from (1) and (7) above) result in complex multidimensional surfaces which are the geometric representations of possible solutions to the AFC process. In practice, it is necessary to ensure that the number of unknowns is always less than the number of equations, or the problem can not be solved. If $M$ is the number of samples and $\mathrm{N}$ is the number of trace elements and isotope ratios, then: 
$N \geqslant \frac{2 M}{M-2}$, i.e. for five samples we need a minimum of four elements (which can, but need not, include isotope ratios) per sample.

Clearly for any number of samples, the solutions are better constrained if more trace elements and isotope ratios are used. However, every additional trace element, or isotope ratio, generates a further $2 \mathrm{M}$ equations to solve and that may be restricted by the size of the computing system. Partly to accommodate possible computing restrictions the intention is to carry out AFC calculations in two stages. The first stage will consider the full range of magma compositions: the programme working through from sample 1 (assumed Co) to 2 , from 1 to 3 , from 1 to 4 , etc., but both the composition of the assimilant and the bulk partition coefficient D for any element will be assumed to be the same throughout. This should yield reasonable average values for $C_{a}$ and $D$, and actual changes in $\mathrm{D}$, within the suite will be detected by sudden variations in the calculated values of $r$.

In the second stage, the whole magma suite will be broken down into subsets of samples with similar compositions within which D may reasonably be assumed to be constant. $C_{a}$ is still held to be the same for the whole suite and $\mathrm{r}$ and $\mathrm{F}$ are likely to change little within any subset. The

Table 1 - Analytical Results

\begin{tabular}{|c|c|c|c|c|c|c|c|c|c|}
\hline Samplea & MV1 & MV2 & MV3 & MV4 & MVS & MV6A & MV6B & MV7 & MV8 \\
\hline $\mathrm{SiO}_{2}$ & 50.8 & 52.7 & 52.5 & 55.7 & 53.5 & 62.2 & 57.9 & 67.8 & 67.3 \\
\hline $\mathrm{TiO}_{2}$ & 1.30 & 1.11 & 1.19 & 1.44 & 1.07 & 1.34 & 1.67 & 0.95 & 0.98 \\
\hline $\mathrm{Al}_{2} \mathrm{O}_{3}$ & 14.0 & 15.8 & 14.8 & 13.7 & 14,3 & 12.9 & 13.2 & 12.8 & 13.0 \\
\hline FeOO & 14.3 & 11.5 & 13.3 & 14.3 & 13.2 & 10.6 & 13.2 & 6.91 & 6.99 \\
\hline $\mathrm{MnO}$ & 0.19 & 16 & 0.19 & 0.19 & 0.20 & 0.15 & D.17 & 0.12 & 0.12 \\
\hline $\mathrm{MgO}$ & 6.51 & 5.87 & 6.19 & 3.79 & 6.09 & 2.47 & 3.15 & 1.48 & 1.75 \\
\hline $\mathrm{cos}$ & 11.0 & 10.1 & 9.38 & 8.35 & 10.0 & 4.94 & 6.09 & 3.47 & 3,09 \\
\hline $\mathrm{N}_{2}{ }_{2} \mathrm{O}$ & 2.51 & 2.37 & 2.41 & 270 & 2.22 & 2.86 & 3.03 & 3.01 & 3.07 \\
\hline $\mathrm{K}_{2} \mathrm{O}$ & 0.65 & 1.11 & 1.10 & 0.95 & 0.48 & 3.22 & 2.66 & 3.78 & 4.08 \\
\hline $\mathrm{P}_{2} \mathrm{O}_{5}$ & 0.16 & 0.20 & 0.19 & 0.20 & 0.15 & 0.25 & 0.29 & 0.25 & 0.29 \\
\hline & 101.4 & 100.8 & 101.3 & 101.3 & 101.2 & 101.0 & 101.3 & 100.6 & 100.6 \\
\hline Be & 242 & 369 & 462 & 462 & 317 & 382 & 598 & 643 & 862 \\
\hline Rb & 21 & 31 & 25 & 55 & is & 127 & 110 & 160 & 178 \\
\hline St & 181 & 169 & 238 & 218 & 241 & 163 & 189 & 141 & 131 \\
\hline $\mathrm{Zx}$ & 105 & 127 & 150 & 186 & 118 & 223 & 221 & 254 & 252 \\
\hline $\mathrm{Nb}$ & 7 & 9 & , & 14 & 8.0 & 19 & 7 & 21 & 21 \\
\hline $\mathbf{Y}$ & 27 & 25 & 38 & 37 & 25 & 42 & 41 & 42 & 78 \\
\hline La & 10.6 & 16.1 & 30.6 & 27.3 & 15.7 & 37.6 & 34.9 & 40.7 & 44.2 \\
\hline Ce & 24.4 & 35.5 & 45.4 & 56.8 & 32.8 & 76.2 & 72.7 & 86.4 & 89.2 \\
\hline Nd & 14.6 & 20.0 & 29.9 & 29.9 & 17.5 & 36.4 & 36.9 & 40.9 & 44.9 \\
\hline Sm & 3.88 & 4.29 & 6.52 & 6.42 & 4.03 & 7.54 & 7.41 & 8.10 & 9.09 \\
\hline Eu & 1.30 & 1.26 & 1.92 & 1.7 & 1.30 & 1.7 & 1.84 & 1.65 & 1.88 \\
\hline Tb & 0.8 & & & & & 12 & 1.25 & 1.37 & 1.65 \\
\hline$\gamma_{b}$ & 2.77 & 2.32 & 3.29 & 3.50 & 2.32 & 3.76 & 3.99 & 3.61 & 4.80 \\
\hline Lu & 0.42 & 0.37 & 0.53 & & 0.36 & 0.59 & 0.64 & 0.60 & 0.81 \\
\hline$c_{t}$ & 0.91 & 1. & 0.54 & 3.2 & 0.79 & 4.4 & 3.88 & 8.80 & 8.70 \\
\hline HI & 2.78 & 3 & 3.94 & 4. & 2.95 & 6.0 & 6.01 & 6,74 & 6.71 \\
\hline$T_{s}$ & 0.4 & & & & & 1.41 & 1.29 & 1.74 & 1.77 \\
\hline Th & 2.31 & 3.69 & 4.65 & 7.48 & 3.70 & 11.5 & 10.3 & 14,1 & 14.2 \\
\hline 0 & 0. & 0 & o. & 1.4 & 0.9 & 3.5 & 2.3 & 4.8 & 5.4 \\
\hline${ }^{87} \mathrm{Str}^{86} \mathrm{Sr}_{130}$ & 0.70690 & 0.70985 & 0.71029 & 0.71247 & 0.71059 & 0.71673 & 0.71495 & 0.71918 & 0.71896 \\
\hline $14{ }^{13} \mathrm{Nd}^{144} \mathrm{Nd}_{13}$ & 512328 & - & 0.512080 & 0.512130 & 0.512170 & 0.51204 & 0.512110 & 0.51207 & 0.5120 \\
\hline
\end{tabular}

composition of $\mathrm{C}_{\mathrm{a}}$ from stage one offers a good starting position for $\mathrm{C}_{\mathrm{a}}$, and by breaking the magma suite up into subsets it becomes possible to evaluate changes in $\mathrm{r}, \mathrm{D}$, and $\mathrm{F}$ as fractional crystallisation and assimilation proceeds. However, such an analysis can only be undertaken on data sets with enough samples for there to be an adequate number in each subgroup.
ANALYTICAL RESULTS In 1984, nine samples were collected from the Muçum-Vespasiano Correia (RS) road section $\left(29.5^{\circ} \mathrm{S}\right.$ and $\left.53^{\circ} \mathrm{W}\right)$ through basalts and rhyolites of the Serra Geral Formation in the Paraná Basin Sequence. Major and trace elements and $\mathrm{Nd}$ and $\mathrm{Sr}$-isotopes were determined at the Open University and the results are summarised in table 1. Following the work of Bellieni et al. (1984) and Mantovani et al. (1985), these rocks are all within the low P, Ti suite which characterize the southern Paraná.

Simple element-element and element-isotope diagrams are presented in figure 1 illustrating the observed range in composition. Three samples (MV1, MV2, MV3) fall off the main trend and so for the purposes of evaluating this new AFC model they were left out of further calculations. MV5 is thus the most primitive rock considered and is used as the starting composition. Major element closed system fractional

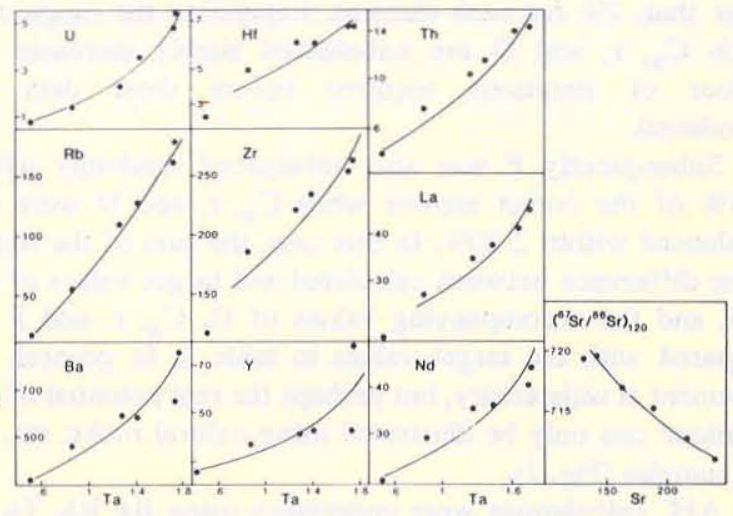

Figure 1- - Element-element and element-isotope diagrams for the observed range in composition. Dots correspond to the measured values and solid lines to the average calculated in this work

crystallization calculations using XLFRAC (Ŝtormer \& Nicholls 1978) and the mineral analyses in table 2, yield an $F$ value of 0.18 for the change in composition from MV5 to MV8 (53.5 to $67.3 \% \mathrm{SiO}_{2}$ ).

AFC CALCULATIONS In order to test the numerical inversion technique, calculations were performed for five elements in a suite of five synthetic samples. $C_{a}$ values were chose to vary between 5 and 100, D between 1.5 and $10^{-3}$, and two $\mathrm{r}$ values of 0.4 and 0.8 were selected for different subgroups of samples. $C_{0}, r, F, D$, and $C_{a}$ were then fixed and the concentration of each element in a more evolved magma $\mathrm{C}_{\mathrm{m}}$ was calculated.

The calculated composition $\mathrm{C}_{\mathrm{m}}$ then became the test sample of known $C_{0}, r, F, D$, and $C_{a}$ with which to evaluate the inversion technique. Initially one of the known values of $\mathrm{F}$ were used, $C_{a}, r$, and $D$ were unbalanced randomly within $\pm 20 \%$ of the correct answers and the programme was asked to recalculate $C_{m}$ and to find its preferred values of $C_{a}$, $\mathrm{r}$, and $\mathrm{D}$ for the five elements. The sum of the square of the difference between calculated and target values of $C_{m}$ is 0.01 , and calculated and target values of $C_{a}, r$, and $D$ agree to 
Table 2 - Average mineral compositions used in XLFRAC*

\begin{tabular}{|c|c|c|c|c|c|c|c|c|c|c|c|c|c|c|}
\hline \multirow[b]{3}{*}{ № of samples } & \multicolumn{3}{|c|}{ Tholeiitic basalts } & \multicolumn{4}{|c|}{ Tholeiitic andesi-basalts } & \multirow{3}{*}{\begin{tabular}{|c} 
Dacites \\
PLAG \\
$(4)$ \\
\end{tabular}} & \multicolumn{3}{|c|}{ Lati-andesites } & \multicolumn{3}{|c|}{ Rhyodacites } \\
\hline & CPX & PLAG & OPC & CPX & PIG & PLAG & OPC & & CPX & PLAG & OPC & CPX & PLAG & OPC \\
\hline & $(7)$ & (10) & (4) & (2) & (2) & (6) & (2) & & (4) & (3) & (2) & (5) & (6) & (4) \\
\hline $\mathrm{SiO}_{2}$ & 52.41 & 52.15 & 0.62 & 51.59 & 52.23 & 53.76 & 0.21 & 52.42 & 51.62 & 54.38 & 0.24 & 51.31 & 53.48 & 0.19 \\
\hline $\mathrm{TiO}$ & 0.55 & 0.07 & 28.08 & 0.77 & 0.35 & 0.08 & 22.5 & 0.08 & 0.74 & 0.08 & 29.62 & 0.61 & 0.07 & 15.46 \\
\hline $\mathrm{Al}_{2} \mathrm{O}_{3}$ & 1.85 & 29.36 & 1.92 & 1.49 & 0.87 & 28.3 & 1.77 & 28.96 & 1.44 & 28 & 0.81 & 1.65 & 27.82 & 1.92 \\
\hline $\mathrm{FeO}$ & 11.41 & 0.84 & 68.16 & 17.72 & 22.1 & 0.78 & 75.1 & 1.05 & 16.79 & 0.95 & 68.85 & 13.84 & 1.2 & 81,88 \\
\hline $\mathrm{MnO}$ & 8 & 1 & 0.84 & 0.38 & & & 0.4 & - & 0.4 & 0.02 & 0.37 & 0.54 & - & 0.52 \\
\hline $\mathrm{Mg}$ & 1. & 2 & - & 15.2 & 19. & & - & - & 12.92 & - & - & 13.74 & - & - \\
\hline $\mathrm{Ca}$ & 17.67 & 13.56 & 0.28 & 12.67 & 4. & 12.37 & 0.02 & 13.05 & 15.79 & 11.83 & 0.05 & 18.02 & 12.05 & 0.03 \\
\hline $\mathrm{Na}$ & 0.25 & 3.71 & 0.1 & 0.16 & 0.05 & 4.28 & - & 4.14 & 0.3 & 4.41 & 0.06 & 0.29 & 5.07 & - \\
\hline $\mathrm{K}_{2} \mathrm{O}$ & - & 0.28 & - & - & - & 0.39 & - & 0.3 & - & 0.33 & - & - & 0.31 & - \\
\hline $\mathrm{Cr}_{2} \mathrm{O}_{5}$ & 0.12 & - & - & 0.02 & 0.02 & - & - & - & & & & & & \\
\hline Total & 100.00 & 100.00 & 100.00 & 100.00 & 100.00 & 100.00 & 100.00 & 100.00 & 100.00 & 100.001 & 100.00 & 100.00 & 100.00 & 100.00 \\
\hline
\end{tabular}

* In addition olivine compositions were taken from Bellieni et al. (1984)

better than $2 \%$ for each element. Expanding the range over which $\mathrm{C}_{\mathrm{a}}, \mathrm{r}$, and $\mathrm{D}$ are unbalanced simply increases the number of iterations required before these data are reproduced.

Subsequently $\mathrm{F}$ was also unbalanced randomly within $\pm 15 \%$ of the corret answer while $C_{a}, r$, and D were still unbalanced within $\pm 20 \%$. In this case, the sum of the square of the difference between calculated and target values of $\mathrm{C}_{\mathrm{m}}$ is 5 , and the accompanying values of $\mathrm{D}, \mathrm{C}_{\mathrm{a}}, \mathrm{r}$, and $\mathrm{F}$ are compared with the target values in table 3 . In general, the agreement is satistactory, but perhaps the real potential of this technique can only be illustrated using natural rocks; viz. the MV samples (Fig. 1).

AFC calculations were undertaken using $\mathrm{Ba}, \mathrm{Rb}, \mathrm{Th}, \mathrm{Y}$, $\mathrm{Zr}$, La, Nd, Hf, Ta, U, Sr, ${ }^{87} \mathrm{Sr} /{ }^{86} \mathrm{Sr}$, and ${ }^{143} \mathrm{Nd} /{ }^{144} \mathrm{Nd}$ for the six samples (MV5, MV4, MV6A, MV6B, MV7, and MV8). MV5 is the assumed starting composition, the calculated steps are MV5 $\rightarrow$ MV4, MV5 $\rightarrow$ MV6B, MV5 $\rightarrow$ MV6A, etc., and table 4 summarises the set limits for $C_{a}, D$, $\mathbf{r}$, and $\mathrm{F}$ within which the programme operates. Starting values of $\mathrm{F}$ were taken to be $5-10 \%$ higher than those calculated for closed system fractionation, and at this stage $\mathrm{C}_{\mathrm{a}}$ and D for each element are held to be the same for all samples.

Table 3 - Test Data

\begin{tabular}{|c|c|c|c|c|c|}
\hline & \multicolumn{5}{|c|}{ ELEMENTS } \\
\hline \multirow{3}{*}{$\begin{array}{l}\mathrm{C}_{\mathrm{a}} \text { target } \\
\text { calc. }\end{array}$} & A & B & $\mathrm{C}$ & D & $E$ \\
\hline & 100 & 80 & 50 & 20 & 5 \\
\hline & 109 & 87 & 54 & 21 & 4.9 \\
\hline \multirow{4}{*}{$\begin{array}{l}\text { D target } \\
\text { calc. }\end{array}$} & $10^{-3}$ & $10^{-2}$ & 0.1 & 0.4 & 1.5 \\
\hline & $1.2 \times 10^{-3}$ & $2 \times 10^{-2}$ & 0.1 & 0.4 & 0.48 \\
\hline & \multicolumn{5}{|c|}{ SAMPLES } \\
\hline & I & II & III & IV & V \\
\hline $\mathrm{r}$ target & 0.4 & 0.4 & 0.4 & 0.8 & 0.8 \\
\hline calc. & 0.45 & 0.35 & 0.45 & 0.82 & 0.82 \\
\hline F target & 0.9 & 0.8 & 0.7 & 0.5 & 0.3 \\
\hline calc. & 0.92 & 0.78 & 0.75 & 0.55 & 0.35 \\
\hline
\end{tabular}

In practice, the computer quickly arrives at values for $\mathrm{r}$ and $\mathrm{F}$ because these are the same for all elements in the sample being modelled. However, while $r$ and $F$ remain
Table 4-Selected limits for $C_{a}, D$, and $F$

\begin{tabular}{lrcll}
\hline & \multicolumn{2}{c}{$\mathrm{C}_{\mathrm{a}}$} & \multicolumn{2}{c}{$\mathrm{D}$} \\
\hline $\mathrm{max}$ & $\max$ & $\min$. & $\max$. & \multicolumn{1}{c}{ min. } \\
$\mathrm{Rb}$ & 1100 & 100 & 0.5 & 0.0005 \\
$\mathrm{Th}$ & 300 & 5 & 0.5 & 0.0005 \\
$\mathrm{Y}$ & 30 & 1 & 0.1 & 0.0005 \\
$\mathrm{Zr}$ & 70 & 3 & 0.9 & 0.05 \\
$\mathrm{La}$ & 250 & 20 & 0.8 & 0.01 \\
$\mathrm{Hf}$ & 85 & 5 & 0.6 & 0.1 \\
$\mathrm{Ta}$ & 14 & 1 & 0.55 & 0.015 \\
$\mathrm{U}$ & 6 & 0.5 & 0.5 & 0.005 \\
$\mathrm{Sr}$ & 8 & 0.5 & 0.3 & 0.0001 \\
${ }^{87} \mathrm{Sr} /{ }^{86} \mathrm{Sr}$ & 800 & 20 & 8.8 & 0.2 \\
\hline
\end{tabular}

constant the computer may continue to explore how changes in $\mathrm{D}$ can be accommodated by altering $\mathrm{C}_{\mathrm{a}}$ in the search for a slightly better fitting for $C_{m}$. Overall reducing $D$, for example, also reduces $C_{a}$ because a lower $D$ results in higher concentrations in the liquid and hence a lower $\mathrm{C}_{\mathrm{a}}$ is required for the same $C_{m} / C_{o}, F$, and $r$. If $D$ is $>0.5, C_{a} / C_{o}$ is very sensitive to changes in $\mathrm{D}$, but at lower $\mathrm{D}$ values changes of several orders of magnitude have little effect on $\mathrm{C}_{\mathrm{a}} / \mathrm{C}_{\mathrm{O}}$. This may imply that $\mathrm{C}_{\mathrm{a}}$ is better determined for elements with very low D values, or simply that at very low D it is relatively unimportant in determining $\mathrm{C}_{\mathrm{m}}$. Work is in progress to evaluate further whether better constrained AFC solutions are available using elements with low or high $\mathrm{D}$, or a combination of both, in case it is desirable to weight elements depending on their likely $\mathrm{D}$ values.

Table 5 summarises the values of $\mathrm{C}_{\mathrm{a}}$ and the bulk distribution coefficient $D$ for each element, and $C_{a}$ is compared with estimates of the bulk crust and upper crustal melts in figure 2. The striking features are the negative $\mathrm{Ba}$ and $\mathrm{Sr}$ anomalies and the related high $\mathrm{Rb} / \mathrm{Ba}$ and $\mathrm{La} / \mathrm{Sr}$ ratios. These appear to be inconsistent with the bulk assimilation of average crustal compositions, but show excelent agreement with the trace element pattern for average syn-collision granites (Pearce et al. 1984) which are regarded as typical upper crustal melts. In general, as indicated above, for any particular values of $\mathrm{F}$ and $\mathrm{r}$ there is some trade off between $\mathrm{D}$ and $\mathrm{C}_{\mathrm{a}}$. 
Table 5 - Values of $\mathrm{Ca}$ and the bulk distribution coefficient $\mathrm{D}$ for each element

\begin{tabular}{l|c|c}
\hline & $\mathrm{Ca}$ & $\mathrm{D}$ \\
\hline $\mathrm{Ba}$ & 185 & 0.003 \\
$\mathrm{Rb}$ & 217 & 0.002 \\
$\mathrm{Th}$ & 11.4 & 0.026 \\
$\mathrm{Y}$ & 17 & 0.30 \\
$\mathrm{Zr}$ & 97 & 0.16 \\
$\mathrm{La}$ & 23 & 0.05 \\
$\mathrm{Hf}$ & 2.3 & 0.11 \\
$\mathrm{Ta}$ & 1.6 & 0.17 \\
$\mathrm{U}$ & 4.6 & 0.001 \\
$\mathrm{Sr}$ & 86 & 1.23 \\
$87 \mathrm{Sr} / 86_{\mathrm{Sr}}$ & 0.7493 & - \\
${ }^{143} \mathrm{Nd} /{ }^{144} \mathrm{Nd}$ & 0.51186 & - \\
\hline
\end{tabular}

However, for elements with low $\mathrm{D}$, changes in $\mathrm{D}$ have little effect on $\mathrm{C}_{\mathrm{a}}$ so that ratios of such elements $(\mathrm{Rb} / \mathrm{Ba}$, $\mathrm{Th} / \mathrm{Ba}$, etc.) in $\mathrm{C}_{\mathrm{a}}$ are well constrained. This is less true for $\mathrm{Sr}$, but the calculated average $\mathrm{D}=1.23$ is consistent with likely crystallizing assemblages, which lends support to the calculated high $\mathrm{La} / \mathrm{Sr}$ in $\mathrm{C}_{\mathrm{a}}$ (Fig. 2).

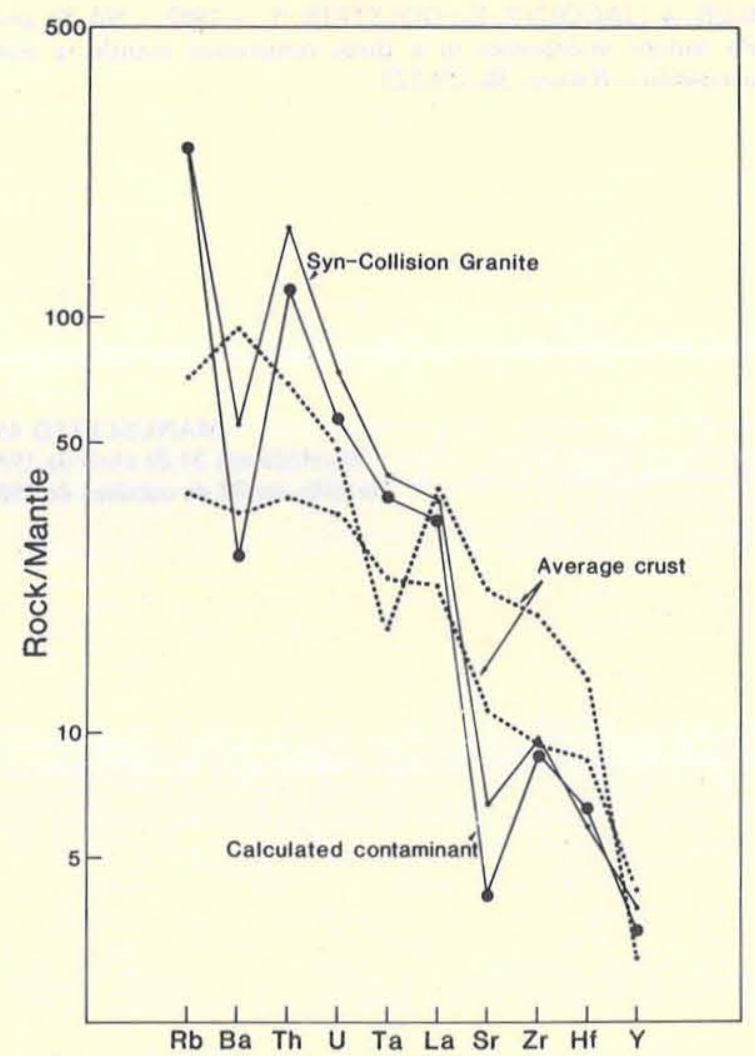

Figure 2 - Composition of the calculated assimilated magma compared to syn-collision granite composition (Harris et al. 1986), and average crust (Weaver \& Tarney 1984)
Radiogenic isotopes are more precisely determined than minor and trace elements, and they are widely regarded as more sensitive indicators of contamination processes. Thus there is a strong case for preferentially weighting the radiogenic isotopes, and this has been done by a factor of $10^{5}$. The calculated contamination trend is illustrated in figure 3 , and the isotope ratios of $\mathrm{C}_{\mathrm{a}}$ suggest that it is both of upper crustal origin (relatively high $\mathrm{Rb} / \mathrm{Sr}$ ) and has a model $\mathrm{Nd}$ age of $1.5 \mathrm{Ga}$. Moreover, the latter is in good agreement with the available model Nd ages on basement rocks in the underlying Brasiliano belt (Mantovani et al. in press).

The F values calculate for AFC and for closed system fractional crystallisation are clearly different. The two are related by $\mathrm{r}$ as follows:

$$
\mathrm{r}=\frac{\mathrm{F}_{\mathrm{AFC}}-\mathrm{FFC}_{\mathrm{FC}}}{1-\mathrm{F}_{\mathrm{FC}}}
$$

For closed system fractional crystallization from MV5 to $\mathrm{MV8} F=0.18$, for $\mathrm{AFC} \mathrm{F}=0.44$, and thus from equation (8) $\mathrm{r}=0.32$ consistent with the AFC model illustrated here (Tab. 5).

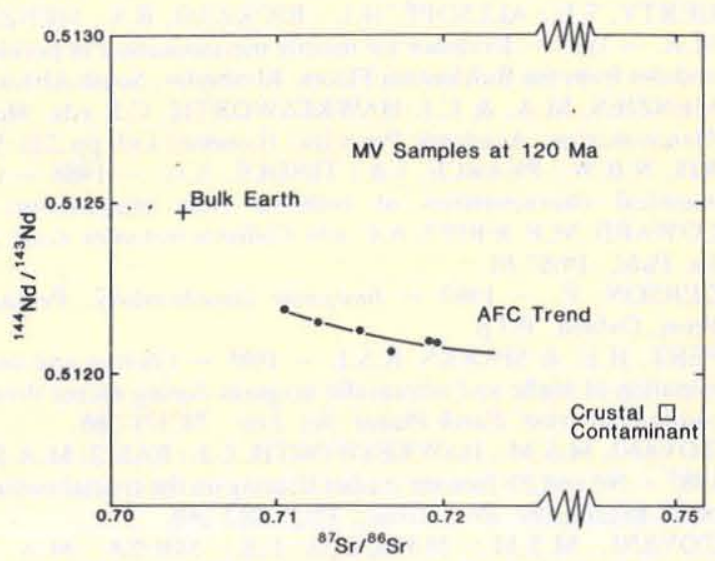

Figure 3 - Nd versus isotope correlation. Both isotope ratios are reduced to $130 \mathrm{Ma}$. Dots correspond to the measured values and the solid line to the AFC trend calculated in this work

SUMMARY STATEMENT The numerical inversion approach to AFC allows us to analyse such processes in some detail. It differs from attempts to fit curves or surfaces through isotope data (e.g. Zindler et al. 1982) because it is formulated in terms of the AFC process, and it considers a range of isotope and minor and trace element data together. The multi-element technique provides better estimates of $F, r$, and $\mathrm{C}_{\mathrm{a}}$ and suggests that the ratios of incompatible elements in the contaminant are well determined. However, as in any non-linear fitting program different initial conditions can lead to different minima, and hence different solutions. Many such solutions are geologically unrealistic, but the extent to which preferred solutions are sensitive to the operator's judgement is still under investigation. The preliminary model illustrated in figures 2 and 3 is simply to demonstrate the inversion approach and it does not yet take account of other geological 
constraints available in the Paraná. In practice, the MV suite is unusual in the number of rocks with intermediate $\mathrm{SiO}_{2}$ values, because most of the Paraná volcanic field is characterised by a bimodal $\mathrm{SiO}_{2}$ distribution. The next stage is to analyse larger data sets which can be broken down into subgroups in order to chart changing $\mathrm{r}$ and $\mathrm{D}$ values with differentiation, to reverse the contamination calculations to investigate the nature of parental "uncontaminated" magmas, and to evaluate models in which the rhyolites represent the crustal contaminant.

Acknowledgements The authors thank P. van Calsteren, W. Shukowsky, D. Wright, N. Rogers, and F.B. Ribeiro for helpful discussions. Travel grants were provided by $\mathrm{CNPq}$ and British Council, and laboratories at the Open University were supported by NERC.

\section{REFERÊNCIAS BIBLIOGRÁFICAS}

BELLIENI, G.; COMIN-CHIARAMONTI, P.; ERNESTO, M.; MELFI, A.J., PACCA, I.G.; PICCIRILLO, E.M. - 1984 Flood basalt to rhyolite suites in the Southern Paraná Plateau (Brazil): paleomagnetis, petrogenesis and geodynamic implications. J. Petrol., 25:579-618.

COX, K.G. \& HAWKESWORTH, C.J. - 1984 - Relative contribution of crust and mantle to flood-basalt magmatism, Mahabaleschwar area, Deccan Traps. Phil. Trans. R. Soc. Lond., A310:627. 641.

DE PAOLO, D.J. - 1981 - Trace element and isotopic effects of combined wall rock assimilation and fractional crystallization. Earth Planet. Sci. Lett., 53:189-202.

ERLANK, A.J.; WATERS, F.G.; HAWKESWORTH, C.J.; HAGGERTY, S.E.; ALLSOPP, H.L.: RICKARD, R.S.; MENZIES, M.A. - 1987 - Evidence for mantle metasomatism in peridotite nodules from the Bultfontein Floors, Kimberley, South Africa. In: MENZIES, M.A. \& C.J. HAWKESWORTH, C.J. eds. Mantle Metasomatism. Academic Press Inc. (London) Ltd. pp.221-311.

HARRIS, N.B.W.; PEARCE, J.A.; TINDLE, A.G. -1986 - Geochemical characteristics of collision zone magmatism. In: COWARD, M.P. \& RIES, A.C. eds. Collision tectonics. Geol. Soc. Sp. Publ., 19:67-81.

HENDERSON, P. - 1982 - Inorganic Geochemistry. Pergamon Press, Oxford, $353 \mathrm{p}$.

HUPPERT, H.E. \& SPARKS, R.S.J. - 1985 - Cooling and contamination of mafic and ultramafic magmas during ascent through continental crust. Earth Planet. Sci. Lett., 74:371-386.

MANTOVANI, M.S.M.; HAWKESWORTH, C.J.; BASEI, M.A.S. $1987-\mathrm{Nd}$ and $\mathrm{Pb}$ Isotope studies bearing on the crustal evolution of SE Brazil. Rev. Bras. Geoc., 17(3): 263-268.

MANTOVANI, M.S.M.; MARQUES L.S.; SOUSA, M.A. de; CIVETTA, L.; ATALLA, L.T.; INNOCENTI, F. - 1985 - Trace element and strontium isotope constraints on the origin and evolution of Paraná continental flood basalts of Santa Catarina State (Southern Brazil). J. Petrol., 26:187-209.

MENZIES, M.A. \& MURTHY, V.L. - 1980 - Enriched mantle: $\mathrm{Nd}$ and $\mathrm{Sr}$ isotopes in diopsides from kimberlite nodules. Nature, 283: 634-636.

PEARCE, J.A.; HARRIS, N.B.W.; TINDLE, A.G. - 1984 - Trace element discrimination diagrams for the tectonic interpretation of granitic rocks. J. Petrol., 25:956-983.

RICHARDSON, S.J.; ERLANK, A.J.; REID, D.L.; DUNCAN, A.R. - 1984 - Major and trace element and $\mathrm{Nd}$ and $\mathrm{Sr}$ isotope geochemistry of basalts from the deep sea drilling project Leg 74 Walvis Ridge transect. In: Init. Reps. DSDP 74, Washington, 739. 754.

STORMER, JR., J.C. \& NICHOLLS, J. - 1978 - XLFRAC: A program for the interactive testing of magmatic differentiation models. Computers and Geosciences, 4:143-159.

WEAVER, B.L. \& TARNEY, J. - 1984 - Empirical approach to estimating the composition of the continental crust. Nature, 310:575-577.

ZINDLER, A.; JAGOUTZ, E.; GOLSTEIN, S. - $1982-\mathrm{Nd}$, Sr, and $\mathrm{Pb}$ isotope systematics in a three component mantle: a new perspective. Nature, 58:519-523. 